\title{
DOI https://doi.org/10.30525/978-9934-26-044-5-35
}

\section{ОРГАНІЗАЦІЯ НАВЧАЛЬНО-ТРЕНУВАЛЬНОГО ПРОЦЕСУ ОРІЄНТУВАЛЬНИКІВ В УМОВАХ КАРАНТИННИХ ОБМЕЖЕНЬ}

\author{
Король С. А. \\ кандидат наук з фізичного виховання та спорту, \\ доцент кафедри фізичного виховання і спорту \\ Сумський державний університет \\ м. Суми, Украӥна
}

На початку березня 2020 року пандемія коронавіруса COVID-19, охопила майже всі країни світу, і раптово вплинула на життєдіяльність людства. Уряди держав оголосили про введення карантинних заходів, щоб зменшити соціальну взаємодію і стримати розповсюдження коронавіруса SARS-CoV-2. Населенню країни не можна було покидати своїх домівок окрім покупок в аптеках та магазинах, всі приватні та державні установи припинили свою діяльність або перейшли на дистанційну форму роботи. Звичайно ці обмеження вплинули і на функціонування спорту. Усі спортивні секції, спортивні клуби припинили свою роботу, було введено заборону на відвідування спортивних площадок, парків, що ще більше обмежило можливості для тренувань. Пандемія безповоротньо змінила цінності, погляди, поведінку людей, включаючи руховий режим пов'язаний з заняттями фізичними вправами та спортом, що вже зараз і в найближчому майбутньому будуть мати негативні прояви на показниках здоров'я населення [3, с. 2].

Оскільки один 3 головних принципів спортивної підготовки безперервність тренувального процесу, тож першочерговим завдання тренерів та спортсменів було в короткі строки адаптуватися до нових умов тренувань, та розробити нові форми та методи їх організації та контролю з застосуванням онлайн-технологій.

Найбільшим впливовим фактором для занять спортом в домашніх умовах став мотиваційний фактор, адже на людину впливає велика кількість відволікаючих факторів, відсутність «зовнішньої» мотивації у вигляді тренера, друзів-спортсменів, відсутності спортивного інвентарю. Водночас, саме заняття фізичними вправами в період самоізоляції дозволяли хоч якось компенсувати дефіцит рухової 
активності та знизити нервове напруження і уникнути стресу через вимушену ізоляцію.

Так як найнижчий рівень мотивації до занять спортом є у дітей, які займаються на етапах початкової та попередньої базової підготовки, то тренерам необхідно було врахувати цей фактор, як визначальний, щоб не втратити свій контингент в начальній групі [2, с. 147]. Оскільки однісї стратегії переходу в дистанційний режим не було, то ж в школах України почали використовувати такий веб-сервіс, як Google Classroom, що дозволяє швидко створити та розіслати завдання учням та отримати оцінку оцінку за його виконання. Тренера зі спортивного орієнтування м. Суми також почали використовувати Google Classroom для забезпечення теоретичної підготовленості учнів 3 основ спортивного орієнтування. Це дозволило швидко організувати вихованців спортивної школи та не втратити зв'язок $з$ ними. Було розроблено презентації щодо правил змагань, особливостей планування та проходження різних видів дистанцій, технічних та тактичних основ орієнтування, особливостей щодо правильності вибору варіанту подолання ділянки дистанції, самоконтролю під час занять фізичними вправами, методики тренування тощо. Освоєння навчального матеріалу орієнтувальниками перевірялося тестуванням та обговорювалися результати в он-лайн режимі через Google Meet.

Для забезпечення технічної підготовки в умовах карантинних обмежень застосовувалася комп'ютерна гра-тренажер спортивного орієтування Catching Features, де вихованці окрім звичайних індивідуальних гонок 3 розподіленого старту, проти комп'ютерних опонентів, могли змагатися між собою в режимі мультиплейера і змагань в реальному часі. Цікавим $є$ також те, програма дозволяє загрузити карти з OCAD'a і бігати картами свого міста або різних країн світу. Гра сприяє розвитку таких техніко-тактичних елементів, як читання карти, «пам'ять карти», зіставлення ii $з$ місцевістю, вибір раціонального шляху для переміщення, контроль напрямку переміщення та розвиває такі психічні функцій як пам'ять, оперативне мислення, увага, що створюють умови для швидкої обробки великого обсягу специфічної інформації. Водночас забезпечення психологічної підготовки, яку розглядають як основу підвищення техніко-тактичної підготовленості реалізовувалася через психотехнічні ігри «лінія уваги», «рахунок цифр», «лабіринт», «умовні знаки», «коридори» тощо [1, с. 71].

Важливим елементом в технічній підготовці орієнтувальника $є$ вибір найбільш оптимального шляху переміщення на ділянці дистанції. За допогомою модуля 2DReRun CoursePlanning орієнтувальники могли намалювати оптимальний на їхню думку шлях переміщення 146 
дистанцією та потім порівняти 3 варіантами інших учасників та ознайомитися 3 найкоротшим варіантом.

Для забезпечення фізичної підготовки в домашніх умовах розміщувалася відео-інструкція щодо тренування, підбирався комплекс вправ переважно кардіо-тренування, силової спрямованості, стречінгу, що не потребував багато місця і додаткового інвентарю. Також використовувалися окремі заняття 3 мобільних фітнес-додатків. Дозування фізичного навантаження здійснювалося відповідно рівня фізичної підготовленості учнів. Для швидкого обміну інформацією типу «питання-відповідь», використовувалися месенджер Telegram. Після завершення режиму самоізоляції, тренування проводилися на відкритому повітрі дистанційно: тренери через веб-сервіс розміщували карту $з$ дистанцією та у зручний для учня час, орієнтувальник долав дистанцію з фіксацією часу проходження дистанції та GPS-треку через телефон або фітнес-годинник, та надсилав дані тренеру. За результатами проходження дистанції підводилися підсумки, та визначали переможців, надсилалися електронні грамоти, що було могутнім мотиваційним фактором для вихованців.

Після послаблення карантинних обмежень тренування проводилися в звичайному режимі, але окремі елементи дистанційного навчання (зокрема теоретичної підготовки, комп'ютерної гри та вправ, самостійні заняття за фітнес-додатками) було збережено і активно продовжує застосовується в навчально-тренувальному процесі.

До вищеподаної дистанційної форми навчально-тренувального процесу були залучені 34 вихованці КДЮСШ № 1 м. Суми груп попередньої базової підготовки (12-15 років). Результати тестування теоретичних знань, за темами, що розглядалися на попередньому етапі підготовки та до карантинних обмежень показали, що лише 11,8$17,6 \%$ в залежності від теми на достатньо високому рівні освоїли теоретичний матеріал (90 балів і більше з 100 б.), що вказує на необхідність посилення теоретичної складової підготовки спортсменів. Результати тестування за темами, що проходили за час карантину показник збільшився до 20,5-32,4\%.

За допомогою психофізіологічних програм комп'ютерного тестування визначалися показники пам'яті та уваги, як на початку так i після карантинних обмежень. Статистично достовірні зміни за цей час встановлено у розвитку психічних функцій: середньостатистичне значення зорової оперативної пам'яті збільшилося на 2,32 бала; обсяг короткочасної пам'яті - відповідно на 1,58 бала; обсяг уваги - 3,13 бала $(\mathrm{p}<0,05)$. 
Так як тестування показників фізичної підготовленості не було проведено перед початком карантинних обмежень, то про динаміку цих показників можна судити лише опосередковано. Звичайно, що на фоні зниження рівня рухової активності показники дещо знизились, та за результатами виступу в змаганнях, що проводилися в червні, 41,1\% підвищили свою спортивну майстерність: 334 вихованців 4 виконали I розряд, 6 - II розряд, 4 - III розряд. Ще одним показником ефективності організації навчально-тренувального процесу за карантинних умов стало те, що жоден вихованець не покинув занять у спортивній секції, тобто у вихованців збереглася стійка мотивація до занять спортом.

Пандемія коронавіруса SARS-CoV-2 спричинила економічну, політичну та соціальну кризи в більшості країнах світу, водночас карантинні обмеження стали каталізатором для впровадження комп'ютерних технологій у всіх сферах життя людства, зокрема спорту. Звичайно вони не можуть замінити повністю особистісного контакту тренера і спортсмена, але дозволяють створити механізми передачі інформації та контролю за їх виконанням в дистанційному режимі на певний проміжок часу.

\section{Література:}

1. Король С. А., Сірик А. С. Удосконалення технічної підготовки у спортивному орієнтуванні на етапі початкової підготовки. Науковий часопис Національного педагогічного університету імені М. П. Драгоманова. Серія 15. Науково-педагогічні проблеми фізичної культури (фізична культура і спорт). Вип. 5 (113). К.: НПУ імені М. П. Драгоманова, 2019. С. 70-73.

2. Яковлев Б. П. Мотиваци и эмоции в спортивной деятельности: учебное пособие. Москва.: Советский спорт, 2014. 312 с.

3. Mutz M., Gerke M. Sport and exercise in times of self-quarantine: How Germans changed their behaviour at the beginning of the Covid-19 pandemic. The International Review for the Sociology of Sport. 00(0). 2020. P 1-12. DOI 10.1177/1012690220934335 